\title{
Staff Career planning and Analysis of Implementation Factors
}

\author{
Meng Zhai ${ }^{1, a, ~}$, Chengcheng $\mathrm{Li}^{1, \mathrm{~b}}$ and $\mathrm{Pu} \mathrm{Li}{ }^{1, \mathrm{c}}$ \\ ${ }^{1}$ School of Management Science and Engineering, Shandong Normal University, Ji’nan 250014, \\ China \\ aliufm69@163.com, b1402045013@qq.com, c1141187104@qq.com \\ *Corresponding author
}

Keywords: Career Planning, Realization, College Students’ Career Planning.

\begin{abstract}
Career planning is the enterprise and employees make joint activities about personal development target and path to implement the demand on both sides. As one of the important content of human resources management, staff career planning plays an irreplaceable role in both individual career development and corporate strategic target realization. However, the degree of recognition and the implementation status of career planning are not very ideal in the domestic. This paper mainly discusses the related concept and content of staff career planning, in addition, through the investing action and research, inspects the degree of the realization about staff career planning in the enterprise, and simply analyses the cause of this phenomenon, explores the problems existing in the staff career planning and puts forward reasonable suggestions.
\end{abstract}

\section{Introduction}

After more than ten years of development, the concept of career planning and management has become more and more widely in the country, and gradually accepted by many enterprises and organizations. As an extremely important part of human resources management field, the importance of career planning to promote the individual and organization development is unquestionable, which is reflected in the ability to establish an effective win-win mechanism: for employees, career planning can help employees to determine the correct direction of career development and make unceasing progress in the organization; for enterprises, career planning can improve the cohesion of enterprises, and is conducive to sustainable development of enterprises. However, even if more and more enterprises are aware of the importance of career planning to realize the corporate strategic target and to be taken seriously, career planning is not a smooth development in China. Employees lack of knowledge of career planning, imperfect enterprise career management system, lack of assessment and incentive mechanism and a single career channel and so on have affected the degree of realization about enterprise staff career planning, so that employees have taken many detours, but also caused a certain obstacle to the enterprises development.

Modern human resource management is no longer just the acquisition and use of employees, It pays more attention to how to develop the potential and play the expertise through self - cognition and positioning, and to gain benefits for enterprise while achieving employee's life goals. And the career planning is not only conducive to personal career development and life value realization, but also to achieve a win-win situation between the organization and employees. Therefore, it plays a very important significance and role in personal career development and organizational development.

\section{Analysis on the Factors Influencing the Career Planning and Realization of Employees}

Now, most enterprises have begun to pay attention to the staff's career management, but there are still many problems in the planning and management process. For example, some enterprises are enthusiastic about the initial management of employee career planning, but this enthusiasm cannot run through. After the enthusiasm of employees and middle managers seems to slowly reduce, so that 
career planning system remains the same, the effect is far less than expected. Many enterprise human resources departments are inevitably caught in such a dilemma. Thus, the present situation of the domestic enterprises career planning and management is formed by the extremely complex factors, cannot be simple and qualitative, need more scientific and comprehensive analysis.

Table 1 Factors that affect the degree of realization

\begin{tabular}{|c|c|c|}
\hline Dimension & Questionnaire question & $\begin{array}{l}\text { Factors that affect the } \\
\text { degree of realization }\end{array}$ \\
\hline \multirow{4}{*}{ Enterprise } & $\begin{array}{l}\text { Whether the enterprise attaches importance to } \\
\text { the employee 's career planning management }\end{array}$ & $\begin{array}{l}\text { The degree of the } \\
\text { enterprise attention }\end{array}$ \\
\hline & $\begin{array}{l}\text { Whether the enterprise is effective for the } \\
\text { employee's career management }\end{array}$ & $\begin{array}{c}\text { The scientifically of } \\
\text { enterprise } \\
\text { management }\end{array}$ \\
\hline & $\begin{array}{c}\text { Whether there is a career guide in the enterprise } \\
\text { (or other career services such as career } \\
\text { counseling agencies) }\end{array}$ & $\begin{array}{l}\text { Guidance support } \\
\text { provided by the } \\
\text { enterprise }\end{array}$ \\
\hline & $\begin{array}{c}\text { Whether the enterprise will adjust staff } \\
\text { positions and train staff based on the staff } \\
\text { career }\end{array}$ & $\begin{array}{l}\text { Rationality of } \\
\text { enterprise human } \\
\text { resource allocation }\end{array}$ \\
\hline \multirow{4}{*}{ Individual } & Do you think career planning is important? & Staff attention level \\
\hline & $\begin{array}{l}\text { Do you understand the knowledge of career } \\
\text { planning? }\end{array}$ & $\begin{array}{c}\text { Employee } \\
\text { understanding }\end{array}$ \\
\hline & Are you actively planning your career? & $\begin{array}{l}\text { Employee attitudes } \\
\text { and initiatives }\end{array}$ \\
\hline & $\begin{array}{l}\text { Have you felt any resistance in the career } \\
\text { planning process? }\end{array}$ & $\begin{array}{l}\text { The rationality of } \\
\text { employee career } \\
\text { planning and design }\end{array}$ \\
\hline Other & $\begin{array}{l}\text { What do you think are the factors that affect } \\
\text { career planning? }\end{array}$ & $\begin{array}{l}\text { Employee job stress } \\
\text { and job performance }\end{array}$ \\
\hline
\end{tabular}

\section{Research on the problems existing in the process of employee career planning}

At present, employees and enterprises in the career planning and management process mainly in the following questions:

\subsection{Management and Staff lack of Awareness of Importance}

When asked about such problems: "your enterprise will provide career planning for employees in the enterprise?" "Do you know how to plan your career?", many employees and managers are unfamiliar with the term "career planning". This shows that many enterprises do not attach importance to the employee career planning. After these years of development, even if the term "career planning" has been "popularized" in the enterprise, the problems reflected in the above examples remain: some businesses and employees do not have an in-depth understanding of the importance of career planning. The concept of career planning is still weak in enterprises and employees, on the one hand, it reflects the lack of people-oriented human resource management and development view, and thinks that only if employees obey management; on the other hand, many employees do not have a clear idea of career planning, they do not know how to plan their career, and they feel confused about their career development.

\subsection{Lack of the Support of Professionals and Corresponding Institutional}

Some enterprises and employees have the awareness and willingness of career management and planning, but lack the support of professionals and corresponding institutions in the professional 
career planning, which undoubtedly affects the career planning. In addition, many enterprises career development channel is too single, which is not conducive to the career management realization.

\subsection{Enterprise Assessment Mechanism is Imperfect, and Lacks of Corresponding Incentives}

Many enterprises are aware of the importance of career planning and are willing to provide career management for their employees, but they are blind to follow the trend. Although these actions have played a certain role in the employees career planning, they often fail to follow, and lack the incentive of follow-up evaluation mechanism and a complete career management system support. It not only wastes the human resource, but also hinders the development of the enterprise.

\subsection{Staff Self-positioning is not Clear and Career Goal is Ambiguous}

Self-analysis and positioning are the first step in the employees career planning, it is also an important basis to determine the direction of career development. However, many employees are not accurate self-positioning, lack of understanding of the professional environment, have no clear career goals, vulnerable to external environment and Other factors affect, easily change their career planning, cannot persevere.

\section{Countermeasures and Suggestions}

\subsection{Improve the Degree of Enterprise Attention, and Guide Employees to Actively Participate}

Enterprises, especially the human resources department and enterprise management, occupies an important position in the employee's career planning. Therefore, enterprises must recognize the importance of career planning for the employees themselves and enterprise, and actively guide employees' career planning. And take corresponding measures to ensure the initiative and initiative of employees in career planning, to ensure the healthy development of employees' career. Specific measures can be established with a set of career planning related to the perfect training, assessment, promotion mechanism. Enterprises allocate reasonably human resources and train positions need talent, at the same time, personal development and strategic objectives of the combination, so that the occupation career planning to play the effect.

\subsection{Improve the Professional Level of Career Planning Guides and Improve Their Scientificalliness}

Employees are the main body of career planning, but staffs do not necessarily have the professional knowledge of the career planning. It tends to give employees the obstacles of the career planning and design and implementation, combat easily staffs enthusiasm, and affect career development. It can be seen that the guidance of specialized career planning staff is indispensable. Therefore, enterprises need to improve the professionalism of career planning mentors, or hire more professional mentors to help employees develop more scientific career planning

\subsection{Conduct Talent Evaluation and Career Planning Consultation for Employees}

Talent evaluation is an important content of human resource management, widely used in foreign enterprises, while the means of talent evaluation are only a mere formality in our country, and have not really been applied to the enterprise human resources management. Therefore, enterprises should carry out talent evaluation for employees, and provide a certain career planning consultation. The evaluation results can help employees to analyze themselves more accurately. Combined with the help and guidance of the consulting department, it helps employees to design more scientific, reasonable and personalized career planning.

\subsection{Establish a Sound Career Planning and Development Mechanism}

Career planning is not done overnight, it takes a long time and is constantly revised and perfected to complete it. Enterprises need to establish a perfect career planning and development mechanism through continuous feedback and amendment, employees career planning is more rational and 
enforceable, so as to continuously improve their professional quality and realize their career development.

\section{Conclusions}

Career planning has played an important role in personal career development and enterprise human resources development and utilization. But there are many various problems and drawbacks in the process of career planning and management, which should not be neglected. Whether career planning can be more popular and healthy in the future, both sides need to pay more attention to it. Only by continuously strengthening the career planning system can the enterprise provide employees with an environment conducive to the healthy development of their careers so as to enhance their talent pool and core competitiveness. At the same time, employees also need to actively participate in, and only by the coordination of corporate strategic objectives and career development goals, enterprises and employees can achieve a win-win situation. It is urgent to strengthen the career planning and design and make it effective.

\section{Acknowledgments}

This work was supported in part by the National Natural Science Foundation of China (No. 61170038, 61472231, 71701115), the National Social Science Foundation of China (No. 14BTQ049), the Shandong Natural Science Foundation(ZR2017MF058), and Special project for Internet development of social science planning special program of Shandong province(17CHLJ23).

\section{References}

[1] Du Yingmei. Career Management (2nd Edition). Beijing, China Development Press, 2011.

[2] Robert·C·Lydon. Career Development and Planning (3nd Edition). Beijing China Renmin University Press, 2010.

[3] Zhang Zaisheng. Career Planning. Tianjin, Tianjin University Press, 2007.8.

[4] Xu Mei, Zhang Shengmei. How do College Students Plan Their Career. Shanghai, Fudan University Press, 2006. 3.

[5] Sun Zonghu, Zhao Shufang. Career Planning Management Practice Manual. Beijing, Posts and Telecommunications Press, 2009.6.

[6] Ma Junjie, Zeng Xiangquan. University Human Resource Management. Beijing, China Renmin University Press, 2007.

[7] Yang Heqing. Career planning. Bei Jing, China Labor Social Security Press, 2005.

[8] Zhang Ying. How to Carry Out Career Planning and Management. Bei Jing, Peking University Press, 2004.

[9] Yu Weixiao. Analysis on the Importance of Career Planning and Management of Employees in Enterprises. Enterprise Herald, 2015, 0(1);133-134.

[10] Hu Ping. Career Development of Enterprise Employees. Value Engineering, 2014, 33 (23); 167-168.

[11] Yuan Wei. Discussion on Employee Career Management. Times report, Academic Edition, 2014, 0(12);282-283.

[12] Li Yang. Research on the Stage of Career Planning in Social Organization. Trade News, 2014, (23);227-227.

[13] Gao Yun. The Problems and Countermeasures of College Students' Career Planning. Journal of 
Liaoning Administration College, 2011, (12):113.

[14] Chang Wanli. Research on the Problems and Countermeasures of College Students' Career Planning. Bei Jing, Beijing University of Chemical Technology, 2010.

[15] Li Yingchun. Reflections on the Career Planning of College Students in China. Higher Education in Jiang Su, 2011, (1). 